\title{
Timing of arrival of the Danube to the Black Sea: Provenance of sediments from DSDP site 380/380A
}

\author{
Arjan de Leeuw $^{1}$ (D) | Andrew Morton ${ }^{1,2} \mid$ Christiaan G. C. van Baak ${ }^{3}$ (D) | Stephen J. Vincent ${ }^{1}$ (I)
}

${ }^{1}$ CASP, Madingley Rise, Cambridge, UK

${ }^{2} \mathrm{HM}$ Research Associates, St Ishmaels, UK

${ }^{3}$ Paleomagnetic Laboratory "Fort

Hoofddijk", Utrecht University, Utrecht, The Netherlands

\section{Correspondence}

Arjan de Leeuw, CASP, Madingley Rise,

Cambridge, UK.

Email: arjan.deleeuw@casp.cam.ac.uk

\begin{abstract}
Estimates for the timing of the arrival of Danube sediment to the Black Sea range from Messinian to Pleistocene; the river is currently the largest sediment contributor, supplying $88 \mathrm{MT} / \mathrm{yr}$. We identify two changes in siltstone provenance-sensitive heavy mineral abundances at DSDP site 380/380A in the southwest Black Sea. Comparison with modern river sediment compositions indicates that siltstones above 571.5 mbsf (metres below sea floor) were supplied by the Danube, while sediments below $651.0 \mathrm{~m}$ were sourced by other supply systems. Palaeo-magnetic, ${ }^{40} \mathrm{Ar} /{ }^{39} \mathrm{Ar}$ and biostratigraphic data reveal that the influx of Danube-supplied sediment to the southwest Black Sea began between $4.36 \pm 0.19 \mathrm{Ma}$ and $1 \mathrm{Ma}$ ago (Zanclean-Calabrian). Our results provide an independent time constraint on palaeogeographic reconstructions of the Pannonian and Dacian basins, which acted as upstream sediment sinks, and suggest that significant volumes of Danube-supplied sediment only started to reach the Black Sea at least $1 \mathrm{Ma}$ after the Messinian Salinity Crisis (5.971-5.33 Ma) had ended.
\end{abstract}

\section{1 | INTRODUCTION}

The Northwest Black Sea contains the largest siliciclastic depositional system within the greater Black Sea basin, with a shelf comprising up to $4 \mathrm{~km}$ of Late Miocene to recent sediments (Munteanu, Matenco, Dinu, \& Cloetingh, 2012). At present, the Danube is the largest sediment contributor to this system, supplying 88 MT of sediment per year, more than $50 \%$ of the total sediment input to the Black Sea basin (Jaoshvili, 2002). Before the Danube was able to reach the Black Sea, it had to infill the upstream lacustrine Pannonian and brackish-marine Dacian basins (Figure 1). Estimates for the timing of arrival of the Danube to the Black Sea range from Messinian (Clauzon et al., 2005) to latest Pleistocene (Maynard, Ardic, \& McAllister, 2012). Constraints on the chronology of progradation of the Danube-Tisza shelf edge across the Pannonian Basin (ter Borgh, Radivojević, \& Matenco, 2015; Magyar et al., 2013) suggest that sediment supplied by the palaeo-Danube and palaeo-Tisza was trapped in the Pannonian Basin until $4 \mathrm{Ma}$ ago. The timing of the infilling of the Dacian Basin, on the other hand, remains largely unconstrained. Moreover, there are no published stratigraphically calibrated provenance records from the Black Sea Basin that constrain the arrival of sediments delivered by the Danube.

The only publicly accessible wells in the Black Sea that penetrate the Late Miocene to Pliocene stratigraphic interval are the Deep Sea Drilling Project (DSDP) cores from Site 380/380A (Leg 42B) drilled in the late 1970 s in the southwest Black Sea (Figure 1; Ross, 1978a). Site 380/380A was situated on the basin floor at a water depth of $2107 \mathrm{~m}$ and penetrated nearly $1100 \mathrm{~m}$ below the sea bed (Figure 2). Turbiditic sediments in the upper part of the drilled interval have been ascribed to the Danube based on their mineralogy (Trimonis, Shimnkus, \& Ross, 1978). The absence of common biostratigraphic markers and the resulting lack of reliable time constraints have, however, greatly hampered the overall interpretation of the geological record preserved in the cores (Ross, 1978b). Recently obtained biostratigraphic (Grothe et al., 2014), magnetostratigraphic and geochronologic results (van Baak, Vasiliev, Palcu, Dekkers, \& Krijgsman, 2016; van Baak et al., 2015b) partially overcome this problem, although the presence of mass transport complexes (MTCs) in the cores complicates the stratigraphic interpretation (Tari et al., 2015). 


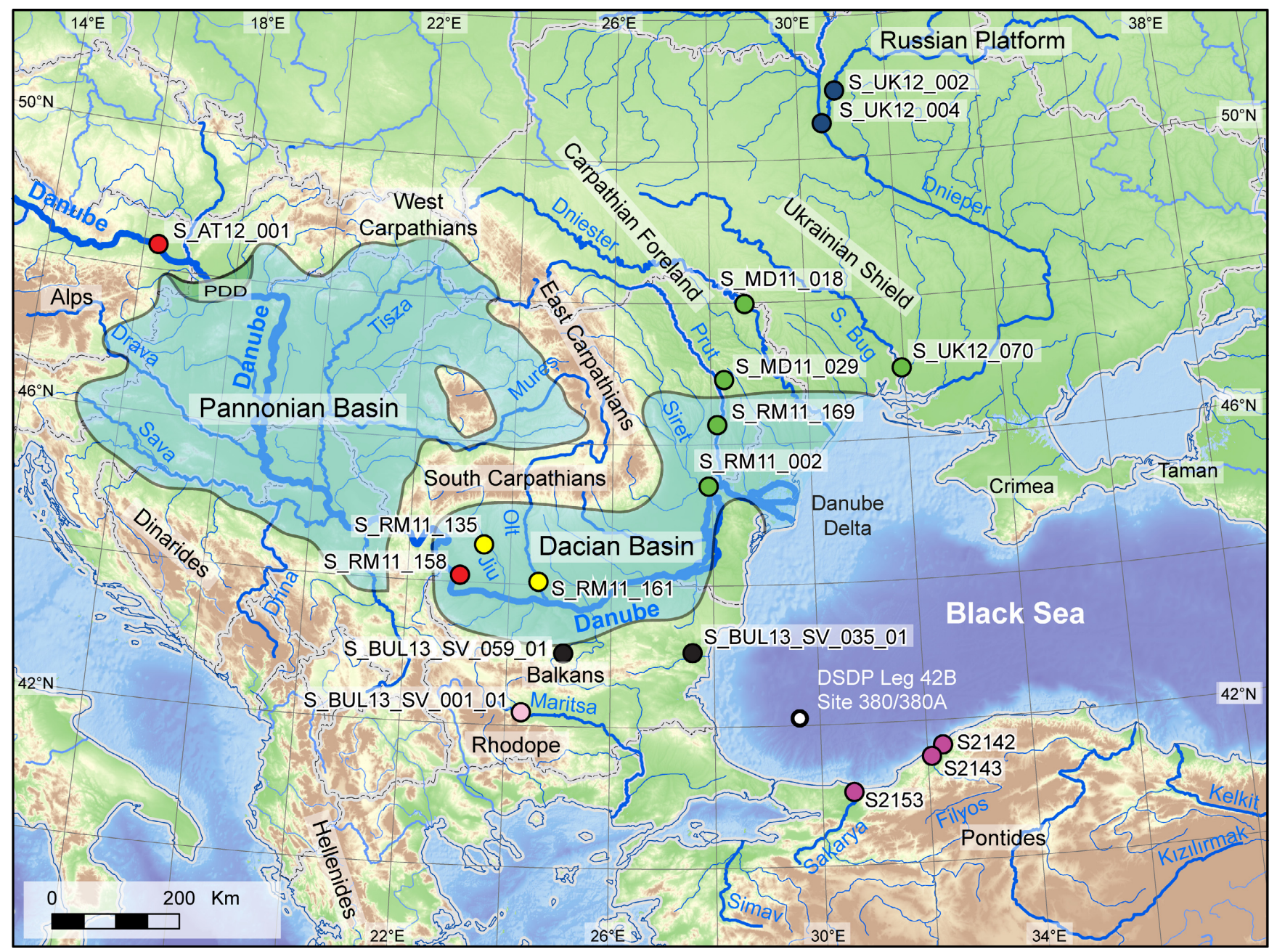

FIGURE 1 Geographic map of the area surrounding the western Black Sea with DSDP Site 380/380A, as well as present-day and ancient river sampling locations indicated. River sampling sites are colour coded to match Figures 4 and 5 . Transparent blue overlays illustrate how the Pannonian and Dacian basins formed lacustrine- and brackish-marine environments in the Late Miocene (Jipa \& Olariu, 2009; Magyar et al., 2013; Stoica et al., 2013) that were subsequently filled with sediment from the surrounding mountains. PDD indicates the approximate position of the Palaeo-Danube Delta at $10 \mathrm{Ma}$ (Magyar et al., 2013) [Colour figure can be viewed at wileyonlinelibrary.com]

This study constrains the timing of the arrival of Danube sediment into the Black Sea by integrating biostratigraphic, magnetostratigraphic, geochronologic and heavy mineral provenance data from the DSDP borehole at site 380/380A.

\section{2 | DSDP SITE 380/380A}

Site $380 / 380 \mathrm{~A}$ penetrated $1073.5 \mathrm{~m}$ below the mud line (Ross, 1978a). The upper approximately $330 \mathrm{~m}$ of sediment (unit I) is predominantly terrigenous and consists of mud and distal turbiditic silts and sands with interbeds of diatomaceous mud (Figure 2; Ross, 1978a). The middle $640 \mathrm{~m}$ of the drilled interval (units II, III and IV) is mainly of biogenic and chemical origin and includes layers of lacustrine chalk, siderite, aragonite and diatomaceous sediments. These are interbedded with occasional mudstones. This middle part includes a 20-m thick coarse-clastic breccia containing laminated dolomite clasts (unit IVd). The lower $100 \mathrm{~m}$ of the drilled interval consist of black shale (unit V).

Numerous biostratigraphic analyses were performed by the shipboard science party, but none were conclusively age diagnostic (Ross, 1978a). Schrader (1978) and Traverse (1978) provided comprehensive and well-integrated palaeo-environmental records, using diatoms (and other organisms with opal skeletons) and palynomorphs, respectively. These studies showed that there were great variations in the Black Sea's salinity and in the climate of the surrounding area (Figure 2). It proved difficult to use these palaeoenvironmental fluctuations as stratigraphic constraints because of a lack of comparative information from the circum-Black Sea area (Ross, 1978a).

In the past decade, there have been significant advances in our understanding of the stratigraphy of the Black Sea. As a result, recent palynologic studies by Popescu et al. (2010) and in particular Grothe et al. (2014) on selected intervals of the DSDP cores have 


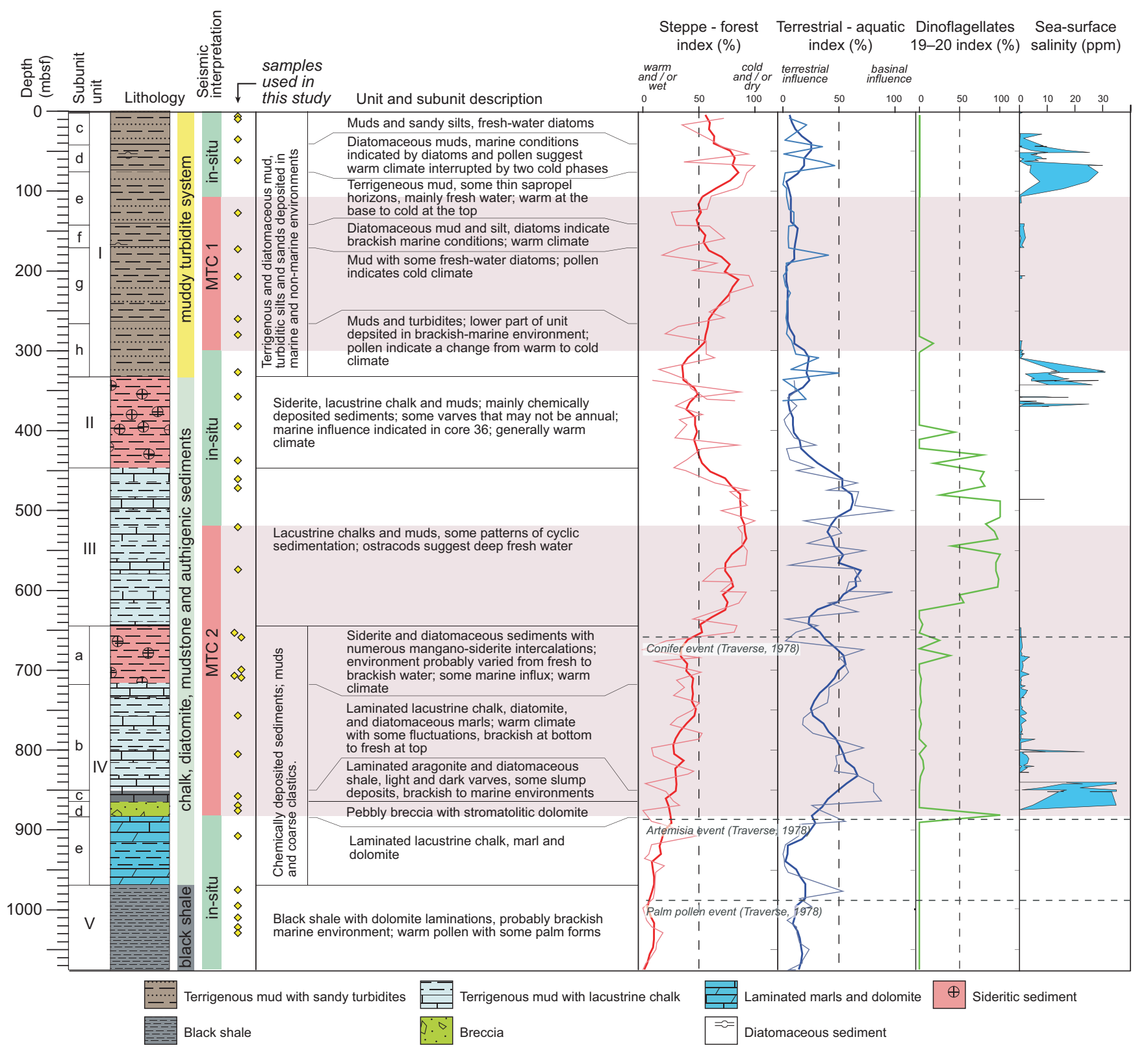

FIGURE 2 Lithology and stratigraphy of DSDP Site 380/380A according to Ross (1978a). Note the presence of two large allochthonous mass transport complexes (MTCs) within the drilled interval (Tari et al., 2015). The steppe-forest and terrestrial-aquatic indexes on the right hand side of the figure are based on palynologic results from Traverse (1978). Thicker lines represent the 5-point average of the thinner lines. Dinoflagellates 19-20 are thought to bloom in brackish to fresh water conditions (Traverse, 1978). Sea surface salinities based on diatom assemblages are from Schrader (1978) [Colour figure can be viewed at wileyonlinelibrary.com]

demonstrated that there is a potential for correlation with sections exposed onshore.

Recent long-offset seismic data for the western Black Sea provide an insight into depositional processes at the well site and show that two large gravity-driven MTCs are present in the cores, spanning the intervals 100-310 m and 520-883.5 mbsf (Figure 2; Tari et al., 2015). 3D seismic data reveal extensional faults in the updip portions of the MTCs and thrust faults with ramp-flat geometries in their downdip parts. Such unconformities occur frequently throughout the Late Miocene to Quaternary of the southwest Black Sea and are related to submarine slope sedimentation (Dondurur, Küçük, \& Çifçi, 2013; Tari et al., 2015). The presence of MTCs in the DSDP cores complicates stratigraphic interpretations. Tari et al. (2015) furthermore showed that the pebbly breccia, which contains shallow-water dolomite clasts (864.5-883.5 m; Figure 2), occurs at the base of the lower MTC and therefore does not provide any evidence for desiccation of the Black Sea during the Messinian as suggested by Hsu and Giovanoli (1979).

\section{3 | HEAVY MINERAL ANALYSIS}

Thirty-three sediment samples were collected from the core at DSDP Site 380/380A (Figure 2). Heavy mineral analyses were performed on 
TABLE 1 Provenance-sensitive heavy mineral ratio data for the silt-grade (30-63 $\mu \mathrm{m})$ and sand-grade $(63-125 \mu \mathrm{m})$ fractions of samples from DSDP Site 380/380A. Mineral ratios are defined as XYi $=\%$ mineral X/(total \% mineral X $+\%$ mineral $Y$ ) (Morton \& Hallsworth, 1994). $\mathrm{ATi}=$ apatite:tourmaline index, $\mathrm{GZi}=$ garnet:zircon index, $\mathrm{RuZi}=$ rutile:zircon index, $\mathrm{MZi}=$ monazite:zircon index and $\mathrm{CZi}=$ chrome spinel: zircon index. Supporting information on heavy mineral assemblages (including grain counts for ratio measurements) is given in supplementary data table S1. Note that sample S_DSDP_018 is a volcanic ash and therefore has markedly different mineralogical parameters to all other samples

\begin{tabular}{|c|c|c|c|c|c|c|c|}
\hline Sample No & Grain size $(\mu \mathrm{m})$ & Stratigraphic level (mbsl) & ATi & GZi & RuZi & $M Z i$ & $C Z i$ \\
\hline S_DSDP_001 & $30-63$ & 3.65 & 67.0 & 90.5 & 56.3 & 0.0 & 12.3 \\
\hline S_DSDP_002 & $30-63$ & 7.33 & 54.0 & 88.1 & 51.5 & 2.0 & 13.0 \\
\hline S_DSDP_004 & $30-63$ & 58.74 & 60.0 & 93.9 & 60.6 & 1.2 & 18.0 \\
\hline S_DSDP_005 & $30-63$ & 124.74 & 65.0 & 88.1 & 57.8 & 1.0 & 15.3 \\
\hline S_DSDP_008 & $30-63$ & 257.69 & 72.0 & 86.6 & 42.2 & 2.0 & 7.4 \\
\hline S_DSDP_009 & $30-63$ & 277.58 & 64.0 & 88.5 & 56.9 & 1.0 & 9.1 \\
\hline S_DSDP_010 & $30-63$ & 324.42 & 62.0 & 90.5 & 50.0 & 0.0 & 12.3 \\
\hline S_DSDP_011 & $30-63$ & 355.19 & 71.0 & 89.0 & 33.3 & 0.0 & 18.5 \\
\hline S_DSDP_015 & $30-63$ & 469.73 & - & - & - & - & - \\
\hline S_DSDP_016 & $30-63$ & 518.67 & 67.0 & 90.5 & 49.5 & 0.0 & 21.3 \\
\hline S_DSDP_017 & $30-63$ & 571.46 & 62.0 & 90.1 & 54.5 & 2.4 & 13.0 \\
\hline S_DSDP_031 & $30-63$ & 650.96 & - & 4.0 & 5.9 & 2.0 & 2.0 \\
\hline S_DSDP_018 & $30-63$ & 656.89 & 99.5 & 15.7 & 1.7 & 0.0 & 0.0 \\
\hline S_DSDP_032 & $30-63$ & 698.09 & - & 21.1 & 9.7 & 0.0 & 0.0 \\
\hline S_DSDP_033 & $30-63$ & 705.71 & - & 16.2 & 11.4 & 0.0 & 0.0 \\
\hline S_DSDP_019 & $30-63$ & 707.57 & - & - & - & - & - \\
\hline S_DSDP_020 & $30-63$ & 754.94 & 76.9 & 69.2 & 25.9 & 4.8 & 4.8 \\
\hline S_DSDP_026 & $30-63$ & 973.53 & 84.0 & 73.2 & 40.5 & 2.9 & 18.0 \\
\hline S_DSDP_027 & $30-63$ & 993.39 & 86.0 & 70.1 & 39.1 & 1.4 & 7.9 \\
\hline S_DSDP_028 & $30-63$ & 1008.24 & 86.0 & 66.7 & 43.5 & 2.9 & 3.8 \\
\hline S_DSDP_029 & $30-63$ & 1020.23 & 81.0 & 67.8 & 40.5 & 0.0 & 14.5 \\
\hline S_DSDP_030 & $30-63$ & 1027.43 & 90.0 & 82.6 & 39.0 & 2.0 & 19.4 \\
\hline S_DSDP_001 & 63-125 & 3.65 & 85.0 & 99.5 & 90.5 & - & - \\
\hline S_DSDP_002 & 63-125 & 7.33 & 81.0 & 97.6 & 71.4 & - & - \\
\hline S_DSDP_003 & 63-125 & 32.57 & 89.0 & 96.2 & 48.2 & 0.0 & 9.4 \\
\hline S_DSDP_004 & 63-125 & 58.74 & 81.0 & 96.6 & 71.1 & 0.0 & 35.0 \\
\hline S_DSDP_005 & 63-125 & 124.74 & 88.0 & 97.1 & 66.3 & 3.3 & 25.6 \\
\hline S_DSDP_006 & 63-125 & 170.25 & 84.0 & 98.4 & - & - & - \\
\hline S_DSDP_007 & 63-125 & 204.74 & 92.0 & 97.1 & 76.5 & - & 30.4 \\
\hline S_DSDP_008 & 63-125 & 257.69 & 84.0 & 95.2 & 50.0 & - & - \\
\hline S_DSDP_009 & 63-125 & 277.58 & 86.0 & 98.0 & 88.1 & - & - \\
\hline S_DSDP_010 & $63-125$ & 324.42 & 91.0 & 99.0 & 82.6 & - & - \\
\hline
\end{tabular}




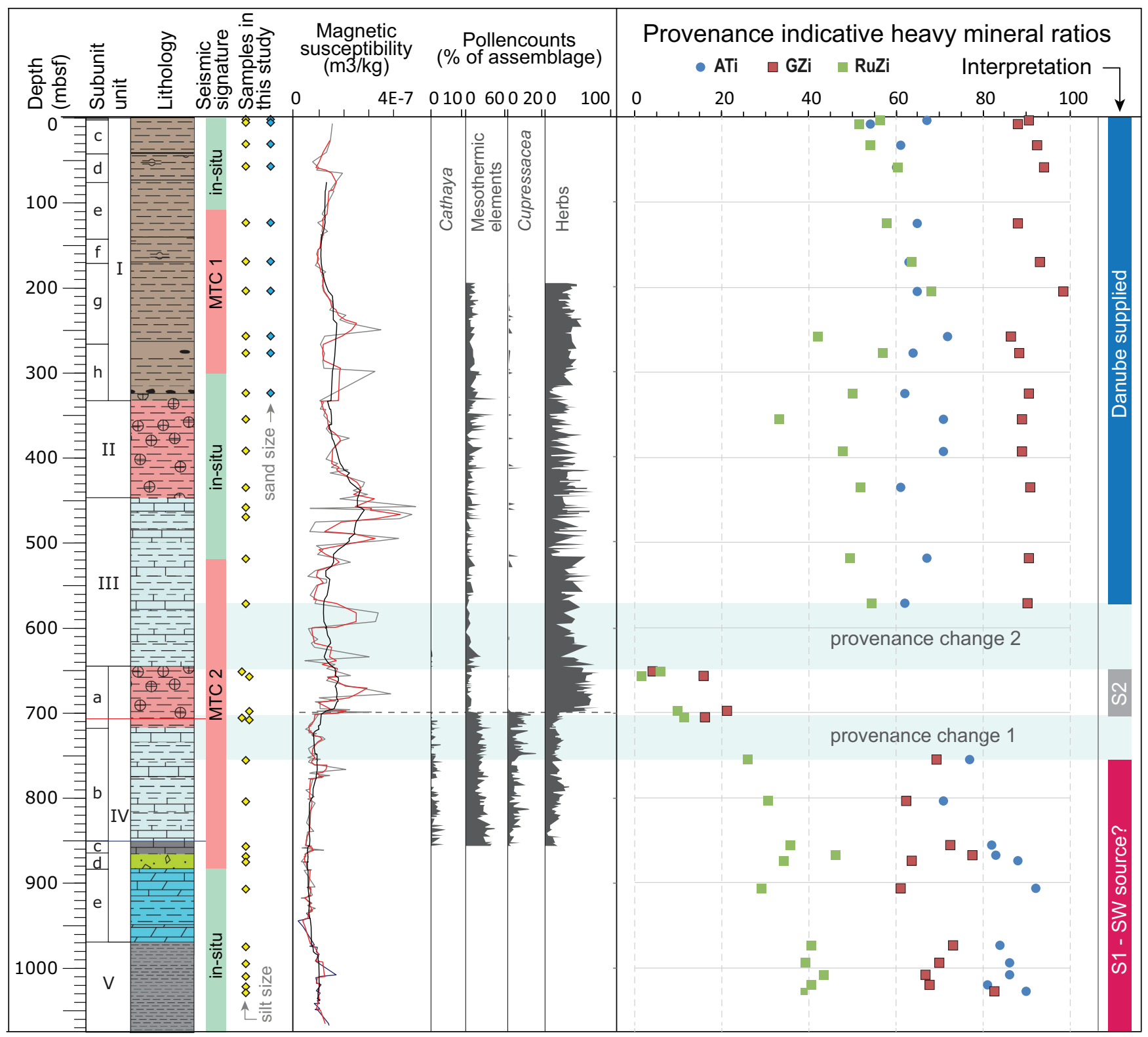

FIGURE 3 Provenance-sensitive heavy mineral ratio plots for silt-grade (30-63 $\mu \mathrm{m})$ material from the DSDP 380/380A core against depth. ATi: apatite-tourmaline ratio, GZi: garnet-zircon ratio, RuZi: rutile-zircon ratio. Magnetic susceptibility is from van Baak et al. (2016): (grey: measured data; red: three-point moving average; black: 25-point moving average). Pollen percentages are from Popescu et al. (2010). See Figure 2 for lithological legend [Colour figure can be viewed at wileyonlinelibrary.com]

the coarse-silt-size fraction of all samples $(30-63 \mu \mathrm{m})$. These were complemented by analyses of the very-fine-sand-size fraction (63$125 \mu \mathrm{m}$ ) of samples from the coarser-grained, upper third of the well. Standard sample preparation and counting techniques were employed, similar to those outlined in Morton (2012). Further details can be found in the supplementary material to this paper.

Owing to the strong diagenetic and hydrodynamic effects on heavy mineral abundances, greater reliance is placed on provenancesensitive mineral ratios (Morton \& Hallsworth, 1994) for provenance interpretation than on mineral abundances. The provenance-sensitive heavy mineral ratio results of the investigated samples are given in
Table 1. Heavy minerals were abundant enough to calculate provenance-sensitive ratios in 29 out of the 33 samples analysed.

Two marked changes in siltstone ATi, GZi and RuZi ratios are apparent (Figure 3). Siltstones in the lower part of the core (below $754.9 \mathrm{mbsf}$ ) have high ATi values (71.0-92.0), intermediate GZi values (61.2-82.6) and low RuZi values (25.9-46.2). Siltstones in the middle part of the core (651.0-707.6 mbsf) have distinctively low GZi (4.0-21.1) and RuZi values (1.7-11.4), while they do not contain sufficient apatite and tourmaline to calculate ATi values. Siltstones in the upper part of the core (above $571.5 \mathrm{mbsf}$ ) have intermediate ATi values (54.0-72.0), high GZi values (88.1-98.5) and intermediate RuZi 
TAB LE 2 Provenance-sensitive heavy mineral ratio data for silt-grade (30-63 $\mu \mathrm{m})$ and sand-grade $(63-125 \mu \mathrm{m})$ material from some of the present-day and palaeo-rivers of the western Black Sea area. ECF: East Carpathian Foreland. See caption of Table 1 for other abbreviations. Supporting information on heavy mineral assemblages (including grain counts for ratio measurements) is given in supplementary data table $\mathbf{S} 2$

\begin{tabular}{|c|c|c|c|c|c|c|c|c|c|}
\hline River samples & Grain size $(\mu \mathrm{m})$ & River & Area & Age & ATi & GZi & RuZi & MZi & $C Z i$ \\
\hline S_AT12_001 & $63-125$ & Danube & Vienna basin & Present day & 87.0 & 97.6 & 65.7 & 9.4 & 3.3 \\
\hline S_RM11_158 & 63-125 & Danube & Dacian basin & Present day & 78.0 & 99.0 & 72.5 & 0.0 & 37.7 \\
\hline S_MD11_029 & $63-125$ & Palaeo-Dniester & ECF & Late Miocene & 70.0 & 88.1 & 40.2 & 2.4 & 0.5 \\
\hline S_MD11_029 & $30-63$ & Palaeo-Dniester & ECF & Late Miocene & 60.0 & 71.4 & 34.8 & 1.0 & 1.5 \\
\hline S_RM11_161 & $63-125$ & Olt & $\begin{array}{l}\text { South } \\
\text { Carpathians }\end{array}$ & Present day & 81.0 & 93.5 & 59.5 & 2.9 & 7.0 \\
\hline S_RM11_169 & $63-125$ & Prut & ECF & Present day & 55.0 & 87.0 & 41.0 & 1.0 & 3.4 \\
\hline S_RM11_002 & $63-125$ & Siret & ECF & Present day & 69.0 & 89.7 & 59.2 & 0.0 & 5.2 \\
\hline S_UK12_004 & 63-125 & Dnieper & $\begin{array}{l}\text { Russian } \\
\text { platform }\end{array}$ & Present day & 12.0 & 60.7 & 14.9 & 0.0 & 0.0 \\
\hline S_BUL13_SV_035_01 & $63-125$ & Kamchia river & Balkans & Present day & 93.0 & 87.7 & 44.4 & 0.5 & 0.5 \\
\hline S_BUL13_SV_035_01 & $30-63$ & Kamchia river & Balkans & Present day & 69.0 & 72.5 & 54.0 & 0.5 & 0.5 \\
\hline S_BUL13_SV_059_01 & 63-125 & Rositsa river & Balkans & Present day & 88.0 & 52.5 & 39.3 & 0.5 & 0.0 \\
\hline S_BUL13_SV_059_01 & $30-63$ & Rositsa river & Balkans & Present day & 66.0 & 34.0 & 35.3 & 0.0 & 0.5 \\
\hline S_BUL13_SV_001_01 & $63-125$ & Maritsa river & Rhodope & Present day & 99.5 & 80.1 & 27.1 & 0.0 & 0.0 \\
\hline S2142 & $63-125$ & Koca River, Bartin & Pontides & Present day & 91.3 & 22.5 & 9.9 & 0.0 & 0.0 \\
\hline S2143 & 63-125 & Filyos River, Saltukova & Pontides & Present day & 90.0 & 80.5 & 32.8 & 0.0 & 11.4 \\
\hline
\end{tabular}

values (42.2-68.2). We interpret these shifts in composition to be due to changes in siltstone provenance.

Heavy mineral compositions in sedimentary systems are grain size dependent (Garzanti, Andò, \& Vezzoli, 2008). Silt-grade heavy mineral analysis is rarely undertaken, and limited amounts of data are available from present-day river silts for comparison. Nevertheless, siltstones from the upper 571.46 mbsf of DSDP well 380/380A have a very similar composition to silt from the present-day Danube (Table 2; Figure 4). A Danube provenance for the upper part of the section is furthermore supported by the composition of turbiditic sandstones present in the upper $330 \mathrm{~m}$ of the well. They have similar 63-125 $\mu \mathrm{m}$ fraction provenance-sensitive heavy mineral ratios to sands from the modern Danube (Table 2; Figure 5) and importantly are distinct, within our much larger sand-grade dataset, from other rivers supplying sediment to the western Black Sea.

The compositions of siltstones from the middle and lower parts of the core are unlike any of the rivers in our dataset. The provenance of these sediments is, therefore, unclear. The stability of the heavy mineral assemblage from the $651.0-707.6 \mathrm{mbsf}$ interval strongly suggests a recycled provenance, while the assemblage from the interval below 754.9 mbsf is indicative of a greater direct input from crystalline rocks. It is unlikely that the observed changes in heavy mineral assemblage reflect variations in the type of sediment supplied from the hinterland of the Danube. The catchment of this river includes a wide variety of rocks along three different orogens susceptible to different geodynamic factors, which makes a sudden (<3.3 Ma) pervasive change in heavy mineral output improbable. Sediment supply from only a small part of the river's drainage (i.e. the Dacian Basin) would likely not have been sufficiently voluminous to have had a significant impact at the comparatively distal DSDP $380 / 380 \mathrm{~A}$ site. A climate-induced change in the output of sediment from the Danube's catchment can also be ruled out based on the observed assemblage shifts (see supplementary material). It is thus much more probable that the observed changes in heavy mineral ratios reflect switches in sediment supply system.

Given the compositional dissimilarity to silts from the Danube, Dniester and Balkan rivers (Figure 4), a southerly to southwesterly source is thought plausible for the lowermost, relatively immature assemblage, particularly given the proximity of this margin. In the Black Sea region, sediments with a strongly recycled signature, such as those from the middle interval of the DSDP 380/380A well, have often been attributed to northern, Russian Platform sources (Vincent, 

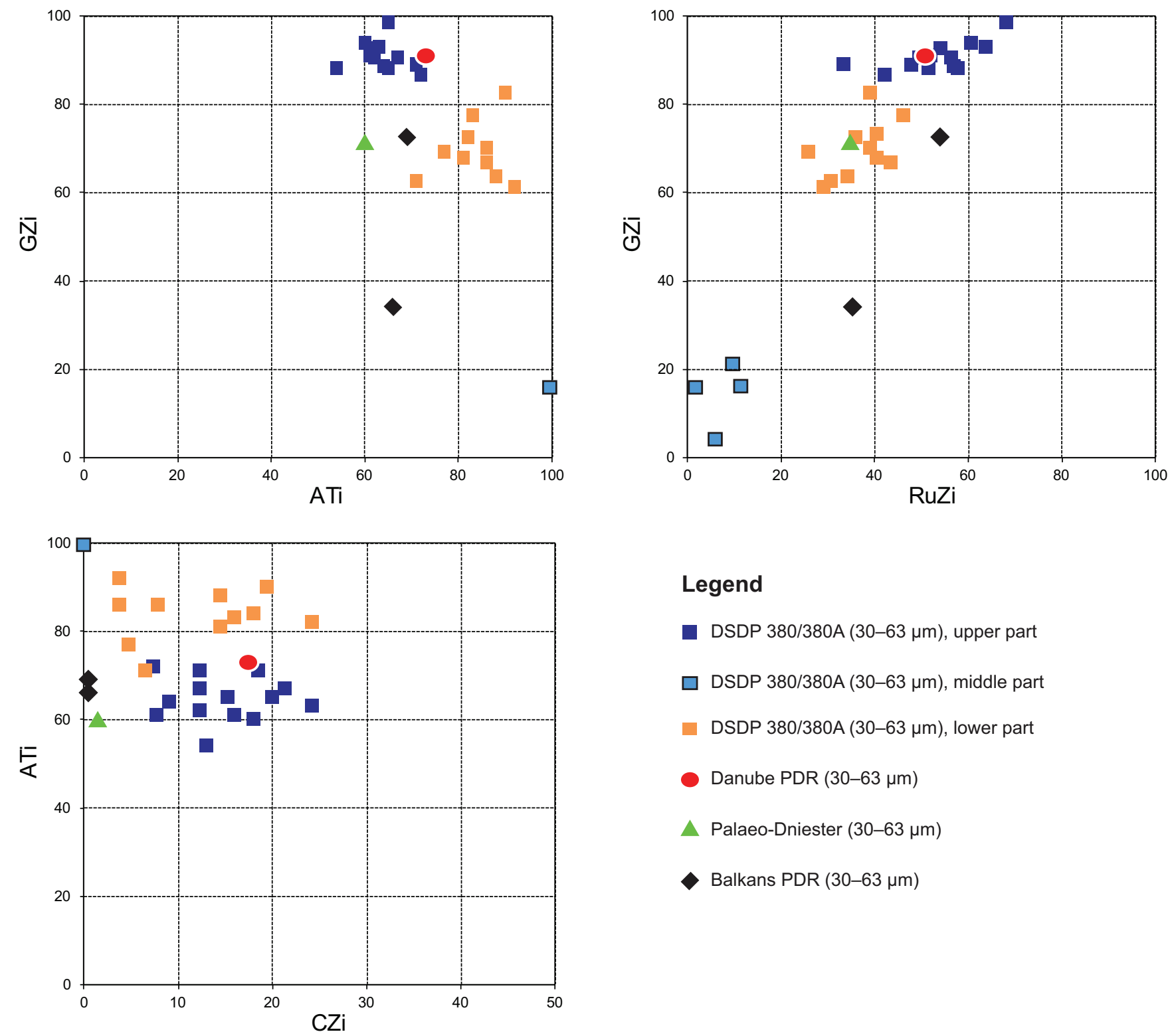

\section{Legend}

DSDP 380/380A (30-63 $\mu \mathrm{m})$, upper part

DSDP 380/380A (30-63 $\mu \mathrm{m})$, middle part

DSDP 380/380A (30-63 $\mu \mathrm{m})$, lower part

Danube PDR (30-63 $\mu \mathrm{m})$

- Palaeo-Dniester (30-63 $\mu \mathrm{m})$

Balkans PDR (30-63 $\mu \mathrm{m})$

FIGURE 4 Provenance-sensitive heavy mineral ratio plots for silt-grade (30-63 $\mu \mathrm{m})$ material from the DSDP 380/380A core and some of the present-day and palaeo-rivers of the western Black Sea area. PDR stands for present-day river. GZi: garnet-zircon ratio, ATi: apatitetourmaline ratio, RuZi: rutile-zircon ratio, CZi: chrome-spinel-zircon ratio. Three of the four samples from the middle part of the DSDP $380 /$ 380A core are shown only on the RuZi-GZi crossplot, because they lack sufficient apatite and tourmaline. The fourth is a volcanic ash dominated by apatite [Colour figure can be viewed at wileyonlinelibrary.com]

Morton, Hyden, \& Fanning, 2013). While the source areas for the lower and middle silt types thus remain to be determined more accurately, silts above 571.46 mbsf are clearly Danube supplied.

\section{4 | AGE CONSTRAINTS}

Stratigraphic correlation of the Black Sea DSDP cores has always been problematic and remains controversial (cf. Grothe et al., 2014; Hsu \& Giovanoli, 1979; Popescu, 2006; Popescu et al., 2010; Ross, 1978b; Stoffers, Degens, \& Trimonis, 1978). The problem is rooted in the absence of common biostratigraphic markers (Ross, 1978a). The enormous changes that are evident in recovered palynomorph (Traverse, 1978) and diatom (Schrader, 1978) assemblages (Figure 2) are indicative of great environmental turnovers, but are not unequivocally age indicative.

Recent magnetostratigraphic, ${ }^{40} \mathrm{Ar} /{ }^{39} \mathrm{Ar}$ and biostratigraphic results provide new age constraints for the sediments recovered at DSDP Site 380/380A (van Baak et al., 2015b, 2016; Grothe et al., 2014), although many uncertainties remain, mainly due to the two large (100s of $\mathrm{m}$ ) MTCs in the drilled interval (Tari et al., 2015). Three important tie points can be established. (1) The 

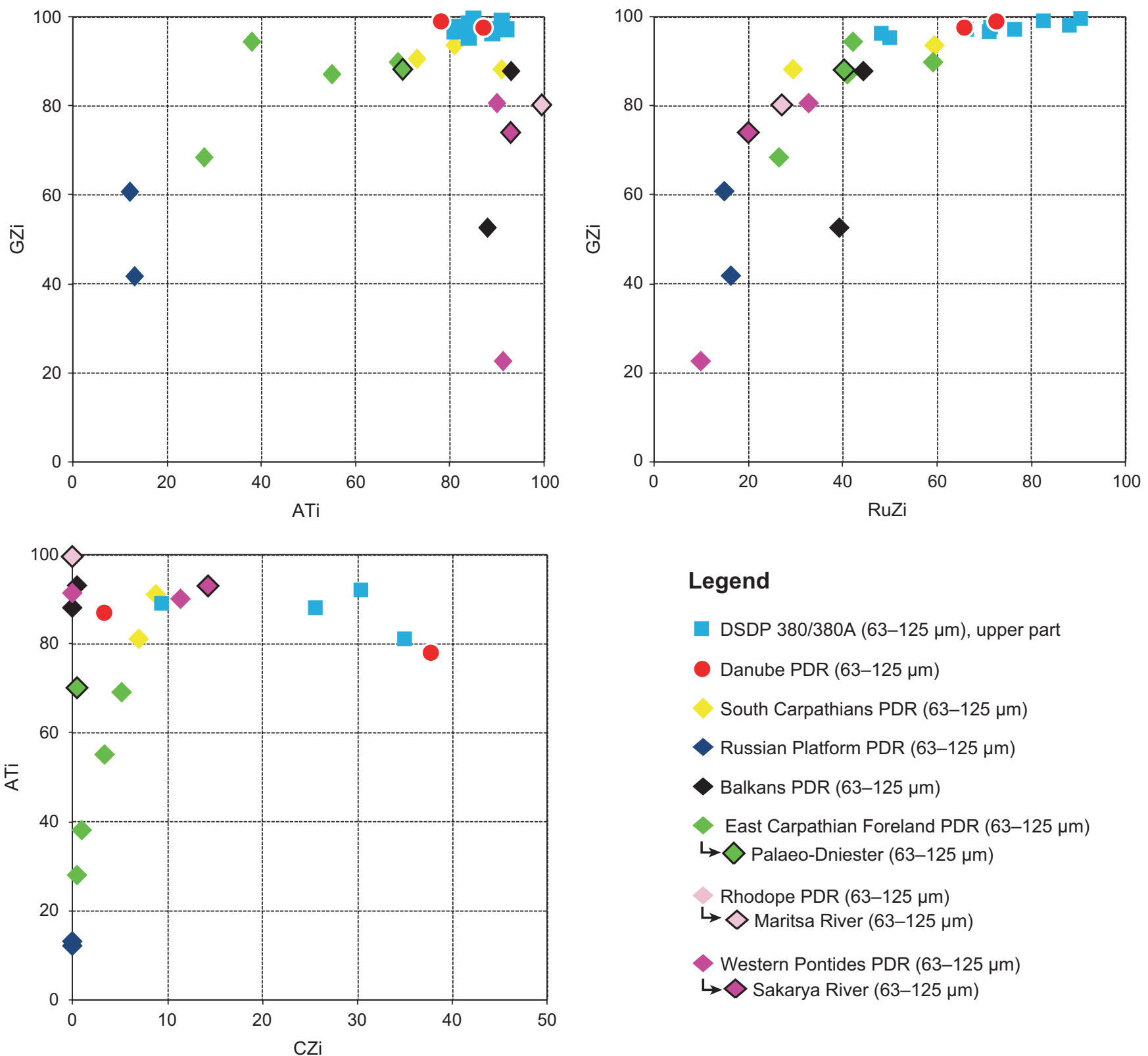

Legend

DSDP 380/380A (63-125 $\mu \mathrm{m})$, upper part

Danube PDR (63-125 $\mu \mathrm{m})$

South Carpathians PDR (63-125 $\mu \mathrm{m})$

Russian Platform PDR (63-125 $\mu \mathrm{m})$

Balkans PDR $(63-125 \mu \mathrm{m})$

East Carpathian Foreland PDR $(63-125 \mu \mathrm{m})$

$\longrightarrow>$ Palaeo-Dniester (63-125 $\mu \mathrm{m})$

Rhodope PDR (63-125 $\mu \mathrm{m})$

$\longrightarrow \diamond$ Maritsa River $(63-125 \mu \mathrm{m})$

Western Pontides PDR $(63-125 \mu \mathrm{m})$

Sakarya River (63-125 $\mu \mathrm{m})$

FIGURE 5 Provenance-sensitive heavy mineral ratio plots for sand-grade (63-125 $\mu \mathrm{m})$ material from the upper $330 \mathrm{~m}$ of the DSDP $380 /$ $380 \mathrm{~A}$ core and some of the present-day and palaeo-rivers of the western Black Sea area. PDR stands for present-day river. Note the shift in ratio values when compared with the silt-grade results [Colour figure can be viewed at wileyonlinelibrary.com]

magnetostratigraphic polarity pattern of in situ unit 2 around 450 mbsf confidently matches the base-Brunhes-Jaramillo interval of the geomagnetic polarity time-scale (Figure 6). This suggests a $1 \mathrm{Ma}$ age for this level. (2) A volcanic ash intercalated at $706.8 \mathrm{mbsf}$ yields a $4.36 \pm 0.19 \mathrm{Ma}{ }^{40} \mathrm{Ar} /{ }^{39} \mathrm{Ar}$ age (Figure 6; van Baak et al., 2015b). (3) Palynomorph and diatom data (Figure 2; Schrader, 1978; Traverse, 1978) indicate that there was a major transgression in Unit IVc. Early Pontian transgressive deposits exposed on Taman have an identical palynomorph stratigraphy, suggestive of a correlation (Grothe et al., 2014). Both on Taman and in the DSDP cores, the transgressive interval occurs just below the base of a long reversed- polarity interval. On Taman, this interval correlates with chron $\mathrm{C} 3 r$ (Krijgsman, Stoica, Vasiliev, \& Popov, 2010), which dates the onset of the transgression at 6.1 Ma (Figure 6).

At Site $380 / 380 \mathrm{~A}$, the interval between the inferred $6.1 \mathrm{Ma}$ transgressive event in Unit IVc and the $4.36 \pm 0.19$ Ma volcanic ash has a magnetic polarity pattern that correlates with the corresponding part of the geomagnetic polarity time-scale in a straightforward fashion (van Baak et al., 2015b). This suggests that the lower part of MTC 2 has a coherent stratigraphy and may have acted as a large slide-block. Thus, insights can be gained from the provenance record within the lower part of this MTC. 
Geological timescale (van Baak et al., 2016)

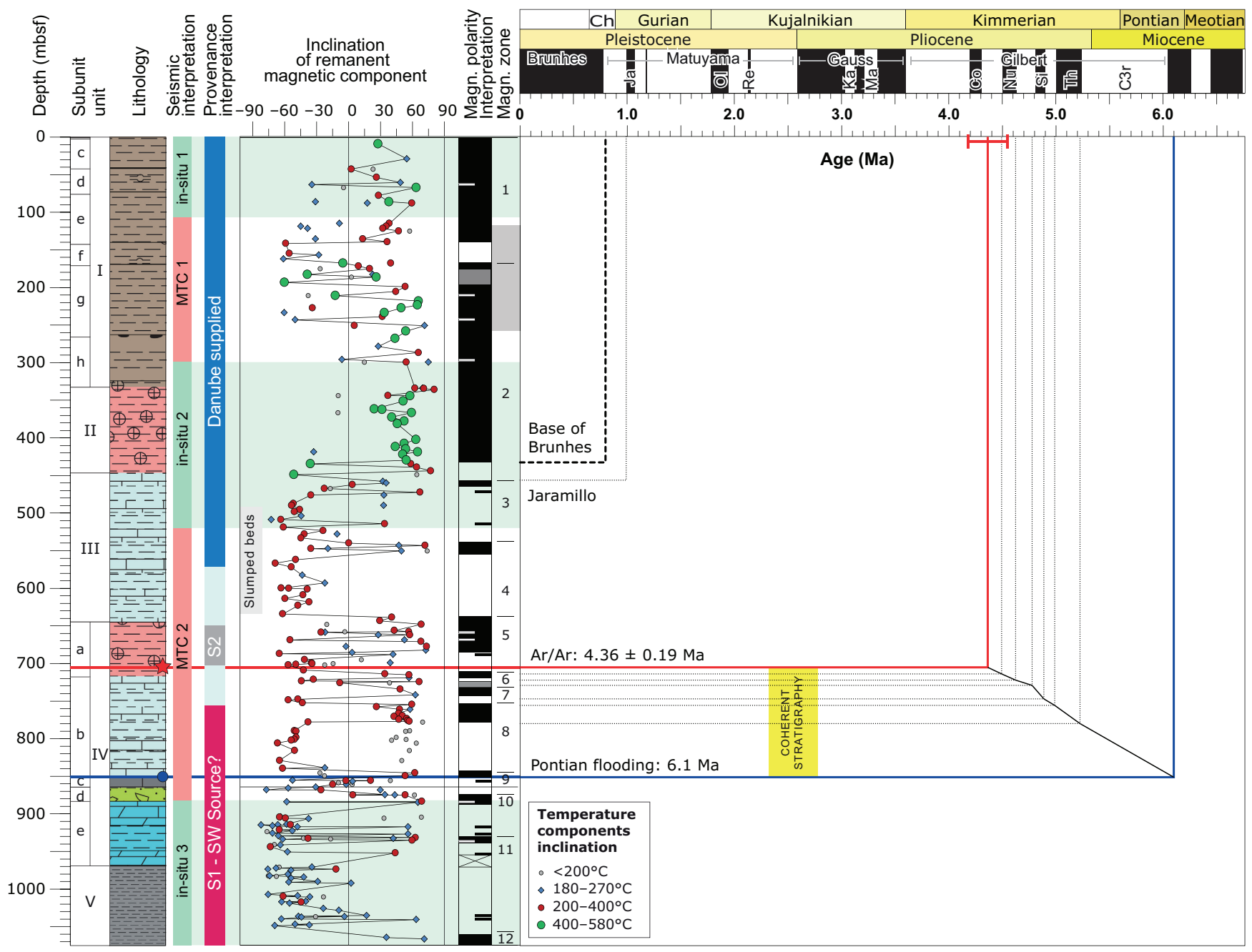

FIGURE 6 Palaeomagnetic results (from van Baak et al., 2016) and age-depth plot for DSDP 380/380A. See Figure 2 for the lithology legend and additional stratigraphic data. The red star at 706 mbsf indicates the position of the ${ }^{40} \mathrm{Ar} /{ }^{39} \mathrm{Ar}$ dated ash layer of van Baak et al. (2015b), and the blue circle indicates the position of the dinoflagellate cyst datum of Grothe et al. (2014) [Colour figure can be viewed at wileyonlinelibrary.com]

\section{CONCLUSIONS AND IMPLICATIONS}

There are two marked changes in the heavy mineral composition of siltstones at DSDP Site 380/380A. These occur between 571.46 and $651.0 \mathrm{mbsf}$ and between 705.7 and 754.9 mbsf (Figure 3) and are interpreted to reflect changes in sediment provenance. The upper change marks the influx of Danube-derived sediments into the southwest of the Black Sea. The composition of siltstone above 571.46 mbsf is indistinguishable from that of present-day Danube sediment (Figure 4). The change occurs above a volcanic ash layer dated at $4.36 \pm 0.19 \mathrm{Ma}$ that is situated at $706.8 \mathrm{mbsf}$ within the coherent stratigraphy of MTC 2 and at least $100 \mathrm{~m}$ below the level of the in situ base-Brunhes-Jaramillo polarity pattern at $1.0 \mathrm{Ma}$, around 450 mbsf (Figures 3 and 6).

Between 571.5 and 330 mbsf, Danube-sourced siltstones occur as sporadic interlayers in a sediment column dominated by chalk, diatomite and authigenic components. From 330 mbsf upwards, the sediment column is dominated by a turbidite system with Danubetype siltstones and sandstones (Figures 4 and 5).

It is noteworthy that there is a marked change in the character of the magnetic susceptibility record around 700 mbsf (van Baak et al., 2016), which might relate to an increase in terrigenous input and/or the arrival of different magnetic minerals in the sediment (Figure 3). This change coincides with the lower provenance change observed. At the same level, a marked switch occurs from palynological assemblages dominated by megamesothermic and mesothermic elements, Cupressaceae and Cathaya to assemblages dominated by herbs (but lacking Anatolian Artemisia steppe elements). This was interpreted as a switch to much colder climatic conditions (Popescu et al., 2010). In our view, the observed change in magnetic susceptibility and the arrival of pollen characteristic of colder conditions might have resulted from a switch from a southerly to a northerly sediment source. 
Our results are in line with recent reconstructions of the progradation of the Danube palaeo-shelf through the Pannonian Basin (Magyar et al., 2013), which suggested that this basin trapped all Danube sediment until at least $4 \mathrm{Ma}$ ago. They are also in line with a source-sink analysis by Maynard et al. (2012), which suggested a Pleistocene arrival of Danube sediment in the Black Sea. Furthermore, there is good agreement with the geology of the eastern Dacian Basin, which became a predominantly fluvial environment during the regional Romanian stage (4.15-1.8 Ma; van Baak, Mandic, Lazar, Stoica, \& Krijgsman, 2015a). Our results cast serious doubt on any scenario involving major erosion and transfer of large amounts of sediment from the Dacian and Pannonian basins to the Black Sea during the Messinian Salinity Crisis (Clauzon et al., 2005; Munteanu et al., 2012), which lasted from $5.971 \mathrm{Ma}$ to $5.33 \mathrm{Ma}$ (Roveri et al., 2014). Our study also highlights that a large volume of the sediments on the northwest Black Sea shelf was likely deposited prior to the arrival of the Danube into the basin.

Better age constraints on the arrival of Danube-sourced material may have been achieved, if it were not for the unfortunate choice of the DSDP 380/380A site. Recent improvements in the understanding of the iron sulphide greigite $\left(\mathrm{Fe}_{3} \mathrm{~S}_{4}\right)$ as a magnetostratigraphic carrier (Roberts, Chang, Rowan, Horng, \& Florindo, 2011; Vasiliev et al., 2008) have overcome the problems experienced when magnetostratigraphic dating was attempted during the initial DSDP mission as demonstrated by the results of van Baak et al. (2016). We, therefore, ultimately agree with Tari et al. (2015) that it is paramount for our understanding of the evolution of the Black Sea that a scientific core is drilled in an area undisturbed by MTCs.

\section{ACKNOWLEDGEMENTS}

We thank Eduardo Garzanti for access to modern river samples from the western Pontides and Michael Flowerdew, Mike Curtis and Andy Whitham for critically reviewing an earlier version of this manuscript. We are also grateful to Gabor Tari for his timely notification of the two large mass transport complexes present in the interval drilled at the DSDP $380 / 380 \mathrm{~A}$ site. Tom Hoyle is thanked for discussions on DSDP palynology. This research used samples provided by the Integrated Ocean Drilling Program (IODP). The staff at the IODP Bremen Core Repository are thanked for their help during sampling. We also thank Stephen Andrews, Mette Olivarius, an anonymous reviewer, editor Max Coleman and an anonymous associate editor for their positive and helpful criticism. The research was funded by CASP's industrial sponsors. It is Cambridge Earth Sciences contribution esc.4048.

\section{ORCID}

Arjan de Leeuw (iD) http://orcid.org/0000-0002-8878-2785 Christiaan G. C. van Baak iD http://orcid.org/0000-0002-2044-2872 Stephen J. Vincent iD http://orcid.org/0000-0002-4495-1276

\section{REFERENCES}

Clauzon, G., Suc, J. P., Popescu, S. M., Marunteanu, M., Rubino, J. L., Marinescu, F., \& Melinte, M. C. (2005). Influence of Mediterranean sea-level changes on the Dacic Basin (Eastern Paratethys) during the late Neogene: The Mediterranean Lago Mare facies deciphered. Basin Research, 17, 437-462.

Dondurur, D., Küçük, H. M., \& Çifçi, G. (2013). Quaternary mass wasting on the western Black Sea margin, offshore of Amasra. Global and Planetary Change, 103, 248-260.

Garzanti, E., Andò, S., \& Vezzoli, G. (2008). Settling equivalence of detrital minerals and grain-size dependence of sediment composition. Earth and Planetary Science Letters, 273, 138-151.

Grothe, A., Sangiorgi, F., Mulders, Y. R., Vasiliev, I., Reichart, G.-J., Brinkhuis, H., Stoica, M., \& Krijgsman, W. (2014). Black Sea desiccation during the Messinian Salinity Crisis: Fact or fiction? Geology, 42, 563-566.

Hsu, K. J., \& Giovanoli, F. (1979). Messinian event in the Black Sea. Palaeogeography, Palaeoclimatology, Palaeoecology, 29, 75-93.

Jaoshvili, S. (2002). The Rivers of the Black Sea: Copenhagen, European Environment Agency, Technical Report 71, 58.

Jipa, D., \& Olariu, C. (2009). Dacian Basin: Depositional architecture and sedimentary history of a Paratethys sea. Geo-Eco-Marina Special Publications, 3, 264.

Krijgsman, W., Stoica, M., Vasiliev, I., \& Popov, V. V. (2010), Rise and fall of the Paratethys Sea during the Messinian Salinity Crisis. Earth and Planetary Science Letters, 290, 183-191.

Magyar, I., Radivojević, D., Sztanó, O., Synak, R., Ujszászi, K., \& Pócsik, M. (2013). Progradation of the paleo-Danube shelf margin across the Pannonian Basin during the Late Miocene and Early Pliocene. Global and Planetary Change, 103, 168-173.

Maynard, J. R., Ardic, C., \& McAllister, N. (2012). Source to sink assessment of Oligocene to Pleistocene sediment supply in the Black Sea. In N. C. Rosen, et al. (Eds.), 32nd Annual GCSSEPM Foundation Bob F. Perkins Research ConferenceNew understandings of the petroleum systems of continental margins of the world Houston, Texas, 27.

Morton, A. C. (2012). Value of heavy minerals in sediments and sedimentary rocks for provenance, transport history and stratigraphic correlation. In P. Sylvester (Eds.), Quantitative Mineralogy and Microanalysis of Sediments and Sedimentary Rocks. Mineralogical Association of Canada Short Course Series, 42, 133-165.

Morton, A. C., \& Hallsworth, C. (1994). Identifying provenance-specific features of detrital heavy mineral assemblages in sandstones. Sedimentary Geology, 90, 241-256.

Munteanu, I., Matenco, L., Dinu, C., \& Cloetingh, S. (2012). Effects of large sea-level variations in connected basins: The Dacian-Black Sea system of the Eastern Paratethys. Basin Research, 24, 583-597.

Popescu, S. M. (2006). Late Miocene and early Pliocene environments in the southwestern Black Sea region from high-resolution palynology of DSDP Site 380A (Leg 42B). Palaeogeography, Palaeoclimatology, Palaeoecology, 238, 64-77.

Popescu, S. M., Biltekin, D., Winter, H., Suc, J. P., Melinte-Dobrinescu, M. C., Klotz, S., ... Deaconu, F. (2010). Pliocene and Lower Pleistocene vegetation and climate changes at the European scale: Long pollen records and climatostratigraphy. Quaternary International, 219, 152-167.

Roberts, A. P., Chang, L., Rowan, C. J., Horng, C. S., \& Florindo, F. (2011). Magnetic properties of sedimentary greigite $\left(\mathrm{Fe}_{3} \mathrm{~S}_{4}\right)$ : An update. Review of Geophysics, 49, RG100246.

Ross, D. A. (1978a). Summary of results of Black Sea drilling. In D. A. Ross \& Y. P. Neprochnov (Eds.), Initial Reports of the Deep Sea Drilling Project. Washington, DC: U.S. Government Printing Office, 1149-1178.

Ross, D. A. (1978b). Black Sea stratigraphy. In D. A. Ross \& Y. P. Neprochnov (Eds.), Initial Reports of the Deep Sea Drilling Project. Washington, DC: U.S. Government Printing Office, 17-26. 
Roveri, M., Flecker, R., Krijgsman, W., Lofi, J., Lugli, S., \& Manzi, V., Stoica, M. (2014). The Messinian Salinity Crisis: Past and future of a great challenge for marine sciences. Marine Geology, 352, 25-58.

Schrader, H. J. (1978). Quaternary through Neogene history of the Black Sea, deduced from the paleoecology of diatoms, silicoflagellates, ebridians, and chrysomonads. In D. A. Ross \& Y. P. Neprochnov (Eds.), Initial Reports of the Deep Sea Drilling Project. Washington, DC: U.S. Government Printing Office, 42, 789-901.

Stoffers, P., Degens, E. T., \& Trimonis, E. S., (1978). Stratigraphy and suggested ages of Black Sea sediments cored during Leg 42B. In D. A. Ross $\&$ Y. P. Neprochnov (Eds.), Initial Reports of the Deep Sea Drilling Project. Washington, DC: U.S. Government Printing Office, 42, 427-450.

Stoica, M., Lazăr, I., Krijgsman, W., Vasiliev, I., Jipa, D., \& Floroiu, A. (2013). Paleoenvironmental evolution of the East Carpathian foredeep during the late Miocene-early Pliocene (Dacian Basin; Romania). Global and Planetary Change, 103, 135-148.

Tari, G., Fallah, M., Kosi, W., Floodpage, J., Baur, J., Bati, Z., \& Sipahioğlu, N. O. (2015). Is the impact of the Messinian Salinity Crisis in the Black Sea comparable to that of the Mediterranean? Marine and Petroleum Geology, 66, 135-148.

ter Borgh, M., Radivojević, D., \& Matenco, L. (2015). Constraining forcing factors and relative sea-level fluctuations in semi-enclosed basins: the Late Neogene demise of Lake Pannon. Basin Research, 27, 681-695.

Traverse, A. (1978). Palynological analysis of DSDP leg 42b (1975) cores from the black sea. In D. A. Ross \& Y. P. Neprochnov (Eds.), Initial Reports of the Deep Sea Drilling Project. Washington, DC: U.S. Government Printing Office, 42, 993-1015.

Trimonis, E. S., Shimnkus, K., \& Ross, D. A. (1978). Mineral composition of coarse-silt fraction of the Black Sea Late Cenozoic sediments. In D. A. Ross \& Y. P. Neprochnov (Eds.), Initial Reports of the Deep Sea Drilling Project. Washington, DC: U.S. Government Printing Office, 42, 413-426.

van Baak, C. G. C., Mandic, O., Lazar, I., Stoica, M., \& Krijgsman, W. (2015a). The Slanicul de Buzau section, a unit stratotype for the Romanian stage of the Dacian Basin (Plio-Pleistocene, Eastern Paratethys). Palaeogeography, Palaeoclimatology, Palaeoecology, 440, 594 613. https://doi.org/10.1016/j.palaeo.2015.09.022 van Baak, C. G. C., Radionova, E. P., Golovina, L. A., Raffi, I., Kuiper, K. F., Vasiliev, I., \& Krijgsman, W. (2015b). Messinian events in the Black Sea. Terra Nova, 27, 433-441. https://doi.org/10.1111/ter.12177

van Baak, C. G. C., Vasiliev, I., Palcu, D. V., Dekkers, M. J., \& Krijgsman, W. (2016). A greigite-based magnetostratigraphic time frame for the late Miocene to Recent DSDP leg 42B cores from the black sea. Frontiers Earth Science, 4, 60.

Vasiliev, I., Franke, C., Meeldijk, J. D., Dekkers, M. J., Langereis, C. G., \& Krijgsman, W. (2008). Putative greigite magnetofossils from the Pliocene epoch. Nature Geoscience, 11, 782-786.

Vincent, S. J., Morton, A. C., Hyden, F., \& Fanning, M. (2013). Insights from petrography, mineralogy and $\mathrm{U}-\mathrm{Pb}$ zircon geochronology into the provenance and reservoir potential of Cenozoic siliciclastic depositional systems supplying the northern margin of the Eastern Black Sea. Marine and Petroleum Geology, 45, 331-348.

\section{SUPPORTING INFORMATION}

Additional Supporting Information may be found online in the supporting information tab for this article.

Data S1 The Supplementary Material is designed to provide additional background information on sample preparation and analysis, and to document and discuss the heavy mineral assemblages obtained.

How to cite this article: de Leeuw A, Morton A, van Baak CGC, Vincent SJ. Timing of arrival of the Danube to the Black Sea: Provenance of sediments from DSDP site 380/380A. Terra Nova. 2018;30:114-124. https://doi.org/10.1111/ ter.12314 